\title{
Abhandlung
}

Uri Gabbay*, Sam Mirelman* and Nicholas Reid*

\section{A Literary Topos of Abundance: Two Emesal Prayers to Enki}

https://doi.org/10.1515/za-2020-0003

\begin{abstract}
This study analyses a literary topos concerning the abundance of natural phenomena, including fresh water, reed beds and fish. The standardised sequence listing such abundant natural features occurs in two previously unpublished tablets containing Emesal prayers concerning the god Enki, published in this article. The Old Babylonian tablet, of unknown provenance, attests to a unique composition. The tablet from Late Babylonian Ur, which is partially paralleled by a previously known manuscript, includes performative indications.
\end{abstract}

\section{Introduction}

The two Sumerian compositions published in this article deal with Enki, perhaps in the context of processions. Both compositions are written in Emesal and belong to the corpus of Emesal prayers, although an identification of the genres and specific compositions to which they belong remains uncertain. They both contain a passage with a well-attested literary topos that describes abundance by referring to natural phenomena such as fresh water, reed-beds, foliage, fish, and longevity. This topos

Article note: We thank Pascal Attinger and Jeremiah Peterson for reading and correcting an earlier version of this article, and for providing us with important references. The tablet 2012.44.5 = x.3.220 is published by permission of the Michael Carlos Museum, Emory University. We thank Dr. Melinda Hartwig, Curator of Ancient Egyptian, Nubian, and Ancient Near Eastern Art, and Stacey Gannon-Wright, Associate Registrar and Collections Manager, for information, photographs of the Emory tablet, as well as accommodating visits to the collection by Reid. The tablet BM 113932 is published by permission of the Trustees of the British Museum. We thank the Vorderasiatisches Museum, and the photographer Olaf $M$. Teßmer, for providing us the photograph of the fragment VAT 22398 published in this article (Figure 3). Uri Gabbay's research on this article was funded by the Israel Science Foundation (no. 135/14).

*Corresponding authors: Uri Gabbay, Department of Archaeology and Ancient Near East, Hebrew University of Jerusalem, Jerusalem, Israel, E-mail: gabbay.uri@mail.huji.ac.il

Sam Mirelman, Department of History, School of History, Religions and Philosophies, School of Oriental and African Studies, London, UK, Email: sm106@soas.ac.uk

Nicholas Reid, Reformed Theological Seminary, Orlando, USA, and Institute for the Study of the Ancient World, New York University, New York City, USA, Email: nreid@rts.edu consists of a stock sequence, which occurs in both standard Sumerian and Emesal compositions, a phenomenon which is relatively unusual, since both groups of texts normally contain their own characteristic stock phrases and passages, which are usually not shared among them. The topos is known mainly from the Old Babylonian period, although it is also attested in one Neo-/Late Babylonian (less likely: Middle Babylonian) Emesal tablet from Nippur (UM 29-16-660+666; see below) and in one small fragment from Nineveh (K.21126; see below). The second composition edited below provides a fuller example of the survival of this topos in the first millennium BCE.

In this article we will first shortly deal with the topos and then philological editions of the texts will be presented.

\section{The Literary Topos of Abundance}

As discussed by Ferrara (1995, 95-117), the full topos consists of a list of localities and the abundant elements that are associated with them; each of these pairs is followed by a verbal phrase, either the same with each of the lines, or alternating, or varying phrases. The full topos is found in the following texts: ${ }^{1}$

- Ninurta F: 24-31

- Nanna K: 3-11

- CT 15, 26-27 (Römer 2001, 195f.:13-21, Text B) (Damu Emesal lament)

- Dumuzi-Inana $\mathrm{D}_{1}:$ 51-59

1 This list updates Ferrara (1995, 95f.). Some of the texts listed by Ferrara are actually only partially similar texts, for which see below. 
- VS 2, 3: 1-17 (Falkenstein 1952/1953) (Emesal prayer; perhaps to Inana) ${ }^{2}$

- VS 2, 1 ii 1-7 (Emesal prayer; perhaps to Nanna)

- N.3381 (Peterson 2008) (Nanna composition)

- Nanna's Journey to Nippur: 332-338 and 341-348 (Ferrara 1973; 1995; Wilcke 1977/78)

- VS 24, 27: 5-22 // BM 113932: 1'-16' (see §IV below) (Emesal prayer to Enki)

- Emory Museum 2012.44.5 = x.3.220, lines 7-14 (see §III below) (Emesal prayer to Enki)

- VS 2, 46 r. $3^{\prime}-5^{\prime}$ (cited by Falkenstein 1952/53, 61) (Emesal prayer; the obverse may deal with Enlil and Inana) (shortened version, see below)

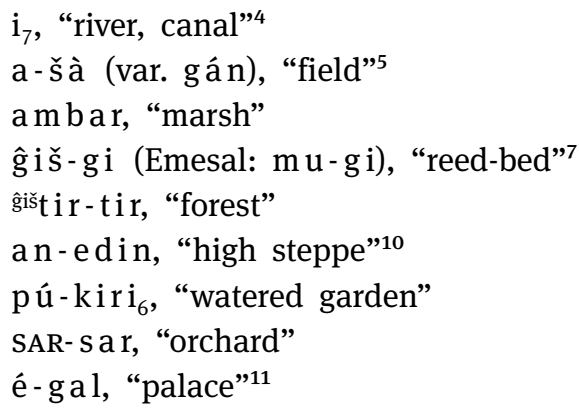

Besides variation between the individual terms, some variation occurs also regarding the structure of the passage. Thus, in Dumuzi-Inana $\mathrm{D}_{1}: 55 \mathrm{f}$. the order of the lines that contain an-edin - ĝiš-maš-gurum and tir-tir š e $g_{9} \check{s}$ e $_{9}$ - b a r is reversed. A few texts omit the line containing the pair SAR-s a r - h $\mathrm{i}-\mathrm{i} \mathrm{z}^{\text {sar }} \mathrm{z}$ à- $\mathrm{h} \mathrm{i}-\mathrm{li}^{\mathrm{sar}}$. $^{12}$

2 Note that the duplicate BM 78983 (unpublished; see S. N. Kramer apud Michalowski 1980, 267) preserves only damaged parts of the first three corresponding lines, before breaking off.

3 We thank J. Peterson for referring us to UM 29-16-660+666 and to K.21126, and for sending us his preliminary transliterations of these tablets.

4 Variant: $i_{7}$ ma h in CT 15, 26: 13 (collated). This is also restored by Falkenstein (1952/53, $60 \mathrm{f}$.) in VS 2, 3 i 1, but the restoration is uncertain (although the duplicate BM 78983: 9 has im-ma, which may indeed reflect ${ }^{\star} i_{7} \mathrm{mah}$ ).

5 The variant $\mathrm{g}$ án is found in CT 15, 26: 14; VS 2, 3 i 2 (syllabic ga ne); and VS 24, 27: $7 \mathrm{f}$. (see §IV below).

6 The writing $\mathrm{ku}_{(6)}-\mathrm{da}$ in some of the texts probably indicates that this was the reading of HI.SUHUR, and probably also that $\mathrm{gu}_{4}-\mathrm{ud}^{\mathrm{ku}}{ }_{6}$ (VS 24, 27: 10 // BM 113932: 4'; see §IV below) should be read phonetically (and not as a variant of GUD = eštu b); see Ferrara (1973, $152 \mathrm{f}$. with references; 1995, 102). Besides these variants, probably all orthographic, two texts have: $\mathrm{ku}_{6} \mathrm{mu}$ šen (Dumuzi-Inana $\mathrm{D}_{1}$ : 53; Emory Tablet: 9, see §III below). The variant in UM 29-16-660+666: 4 is unclear.

7 Variant: $\mathrm{mu}$-SAR in UM 29-16-660+666: 5.
- UM 29-16-660+666 (unpublished; CDLI: P257088, P257094) (Emesal prayer to Enlil)

- K.21126 (unpublished; CDLI: P419440) (Emesal prayer to Nanna) ${ }^{3}$

- For other partial parallels which make use of some but not all elements, see below.

As reconstructed by Ferrara (1995, 96 f.), the full list consists of the following pairs of localities and abundant elements in each line (variants, but not orthographical variants, are listed in footnotes; for structural variants, see below):

a - eštub, "spring waters"

še gu-nu, "mottled barley"

HII.SUHUUR $\mathrm{ku}_{6}$ S u h u rku, "carps"

gi BAD gi henbur, "reed-shoots, stalks"

š eg, še g $_{9}$-bar, "wild sheep, wild goats"9

ĝ iš (Emesal: mu)-maš-gurum, "(tree)"

làl ĝeštin (Emesal: mu-tin), "syrup, wine”

ḩi-i zar zà-h i-lisar, "(plants)”

zi -sù(-ud)- ĝál, "long life”

As noted, the pairs listed above may occur within different types of recurring phrases that create a litany. The most simple is the pairing of the phrases at the beginning of the line, with nothing between the locality and element of abundance, and followed by the same phrase in each line. For example: ${ }^{13}$

8 VS 2, 3 i $7^{\prime}$ and VS 2, 1 ii 2 omit gi BAD, and use $\mathrm{mu}$, rather than $\mathrm{gi}$, before /henbur/; VS 24, 27: 12 probably omits gi BAD as well, although the duplicate BM 113932: $6^{\prime}$ does contain it (see §IV below); UM 29-16-660+666: 5 seems to omit gi BAD as well and to have only ḩé-b[u-ur]. Emory Tablet: 10 omits gi ḩenbur (see §III below). As noted to us by Attinger, in the sequence gi BAD gi he $\mathrm{nbur}$, the reading of BAD is ú š, but when standing alone it may be su mun (as evidenced by Emory Tablet: 10; see §III below).

9 Variants: VS 2, 3 i 8' (Falkenstein 1952/53, 60) and VS 2, 1 ii 3 dár a ši-bar. Emory tablet: 11 ši-bar (not preceded by šeg or dára,

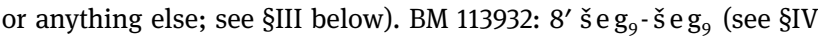
below); UM 29-16-660+666: $5 \mathrm{~s}$ a $\mathrm{g}$ š e? - 'b a r??.

10 Variant: N.3381: 9' (Peterson 2008) edin.

11 Variant: VS 2, 46 r. 5' é-gal lú-gal-e.

12 Ninurta F; N.3381 (Peterson 2008); Nanna’s Journey (2x); Emory tablet (see §III below). N.3381 (Peterson 2008) may omit the final line. VS 2, $46 \mathrm{r}$. $3^{\prime}-5^{\prime}$ contains only the first two lines and the final line and it is unclear whether this reflects a short version or whether this is an abbreviated way of writing the text which was known by heart. For the subject of abbreviation in Emesal texts, see Gabbay/Mirelman (2017, 23-25) and Delnero (2017).

13 Emory Tablet: 7-14 (see §III below). This structure occurs also in VS 2, 1; Nanna's Journey (x2); UM 29-16-660+666; K.21126; perhaps VS 2, 46 (shortened version). 


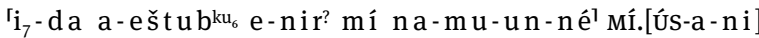
a-ř̌à-ga še-gu-nu 'e'-nir mí na-mu-un-né [Mí].ús$\mathrm{a}-\mathrm{ni}$

ambar-re ku $u_{6}$ ' mušen e-nir mí 'na'-mu-un-né 'Mí.ús'[a-ni] ...

In the river, the spring waters indeed speak kindly to him, his spouse (speaks with kindly words for him),

In the field, the mottled barley indeed speaks kindly to him, his spouse (speaks with kindly words for him),

In the marsh, the fish and birds indeed speak kindly to him, his spouse (speaks with kindly words for him), etc.

In one instance belonging to this group, the pair of localities and elements of abundance is preceded by a nominal phrase, and the copular form na-nam is inserted between the locality and the element of abundance (CT 15, 26-27: 13-21; Römer 2001, 195f.):

i-lu-bi i-mah-e na-nam a-eštub na-ù-tu i-lu-bi gán-e-šè na-nam še-gu-nu na-ù-tu i-lu-bi ambar-e na-nam ku $u_{6}$-da suhurku ${ }_{6}$ na-ù-tu ... That wail is for the mighty river - it (used to) create spring waters, That wail is for the field - it (used to) create mottled barley, That wail is for the marsh - it (used to) create kuda and suhur carps, etc.

A more complex structure is the pairing of the locality and abundance element with two phrases that follow them and alternate every other line. For example Ninurta F: 24-31 (similarly perhaps in N.3381 = Peterson 2008 and Nanna K A: 4-7):

\footnotetext{
$i_{7}-d a$ a-eštub mu-da-ab-si

a-šà-ga še gu-nu mu-da-ab-mú

ambar-ra HI.SUHUUR ${ }^{k_{6}}$ suhurku ku $_{6}$ m-da-ab-si

ĝiš-gi gi BAD gi hoenbur mu-da-ab-mú ...

In the river, spring waters are made plentiful through him (= Ninurta),

In the fields, mottled barley is made to grow through him, In the marsh, kuda and suhur carps are made plentiful through him,

In the reed-bed, reed-shoots and stalks are made to grow through him, etc.
}

In two instances the alternation is even more complex: each pair of locality and abundance elements is divided into two lines forming one temporal sentence, the first line mentioning only the locality (and preceded by a nominal phrase), and the second containing both the locality and abundance element, followed by verbal phrases alternating every other line (see VS 2, 3 and § IV below).

Lastly, Dumuzi-Inana $\mathrm{D}_{1}$ : 51-59 contains a more diverse use of the phrases following the pairs of localities and abundance elements. All phrases begin with the prefix hyé- (once: hu $u$-), and all contain the infix - da-, but the verbal base varies: The first, second, and last lines contain the same verb; the third, fourth, and penultimate line contain the same verb (but different from the previous one); and the second, fifth and sixth lines each contain a different verb:

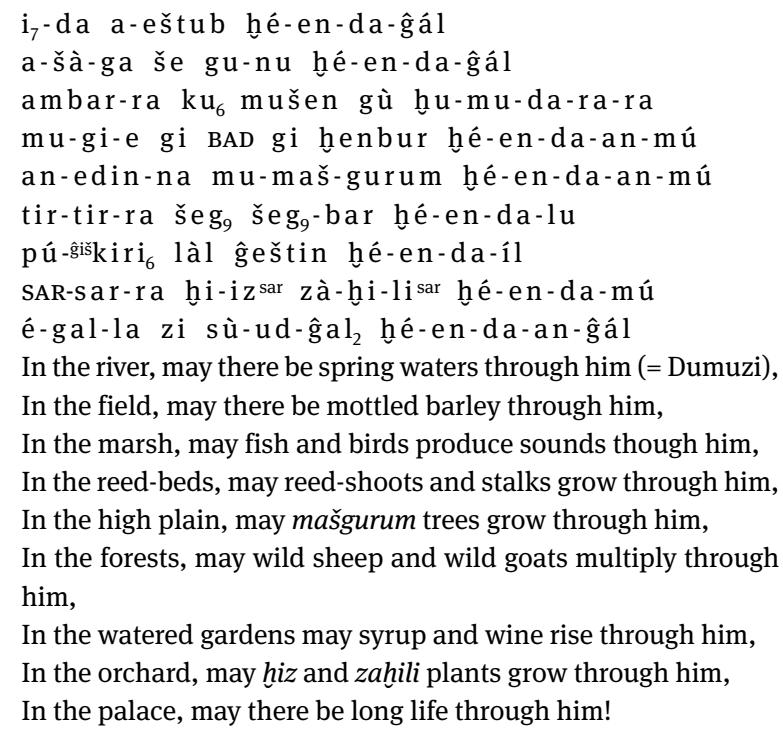

In addition to the texts enumerated and discussed above, there are also a few texts that only partially follow the standard pattern of the topos (Ferrara 1995, 100-110). The text that most closely resembles this pattern is Lamentation over Sumer and Ur lines 498-507 (see Michalowski 1989, 106f.) that contains in its second part almost all the elements from the pattern discussed above, but begins differently, with a similar but not identical theme. Another text (Ludwig 2006, 30: 16'-24'), dealing with Enki in Nippur, also resembles the pattern discussed above in its second part. Another parallel is in the composition Gilgameš and Huwawa, where the enumeration of Huwawa's auras given to different localities is similar to the localities (but without mention of the abundance elements) in the abundance topos (Gilgameš and Huwawa 193-198; see Civil 2003). Lastly, some texts contain a few lines that are known from this pattern. ${ }^{14}$

14 Ninĝišzida C: 17 f.; Rīm-Sîn 15: 19-23 (Frayne 1990, 292, no. 2.14.15); Išme-Dagan D: 45-47; Ur-Namma A: 22f.; Lugale: 359-363; Summer and Winter: 27-32, 52-55; Kramer 1985, 120: 33f.; cf. also Nanna L: 23-25; Enmerkar and the Lord of Aratta: 9f.; Enlil A: 115-123; IddinDagan A: 95-98. 


\section{An Old Babylonian Emesal Composition to Enki}

The Old Babylonian tablet 2012.44.5 = x.3.220 (measurements: $11.3 \mathrm{~cm}$ x $8.9 \mathrm{~cm}$ ), housed in the Michael Carlos Museum, Emory University, contains two compositions or one composition with two sections, separated by a dividing line. The first section is dedicated to Enki and the second seems to be dedicated to the mother-goddess Nintu or Dam(gal)nuna. The provenance of the tablet is unknown. The colophon identifies a certain Lipit-Enlil as the scribe who copied the tablet.

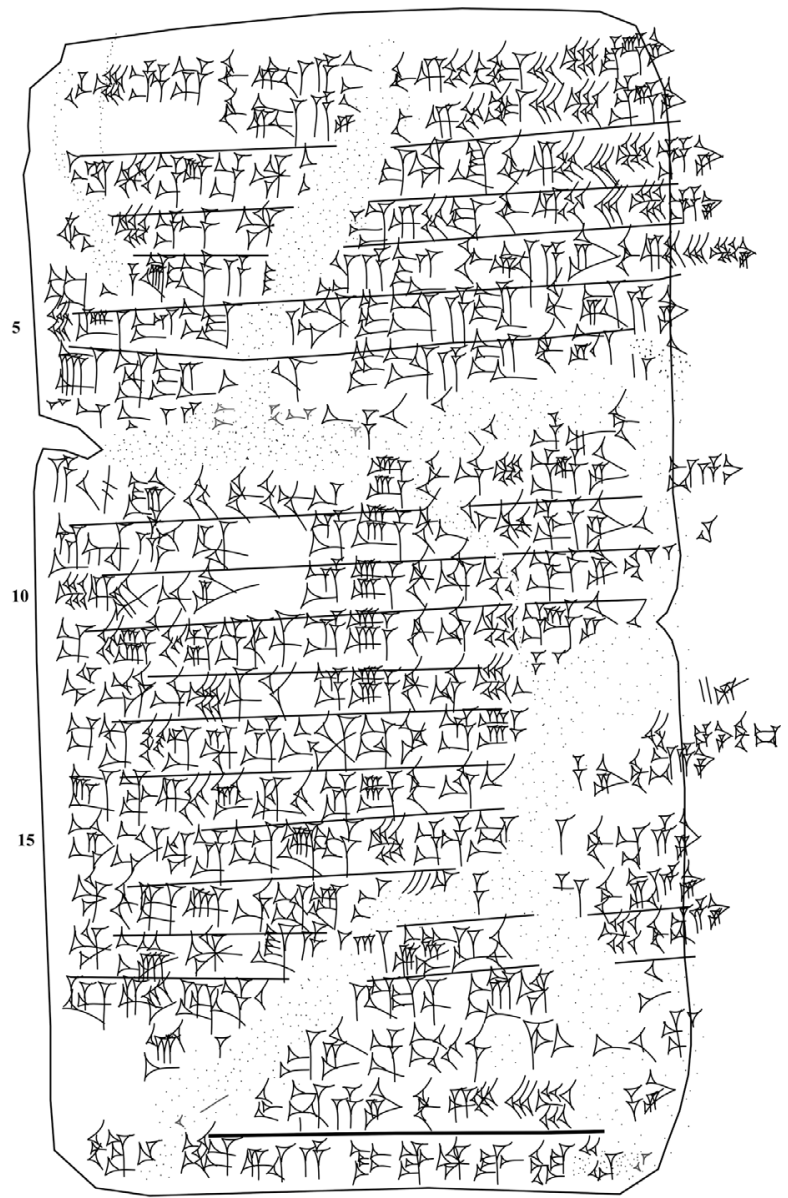

Fig. 1: Emory Museum 2012.44.5 = x.3.220 obverse. Copy: N. Reid
The tablet is written mostly in Emesal, but includes also non-Emesal forms, and uses both standard orthography and syllabic spellings. The first section of the text describes the greetings to Enki by his spouse, perhaps during a procession heading out from Eridu and the E'engur temple. The text contains a passage with the literary topos of abundance discussed above (§II). The second section of the text (or the second composition on the tablet) seems to be directed to Damgalnuna, called here Damnuna, but since the reverse of the tablet is mostly damaged, almost nothing of this section is preserved.

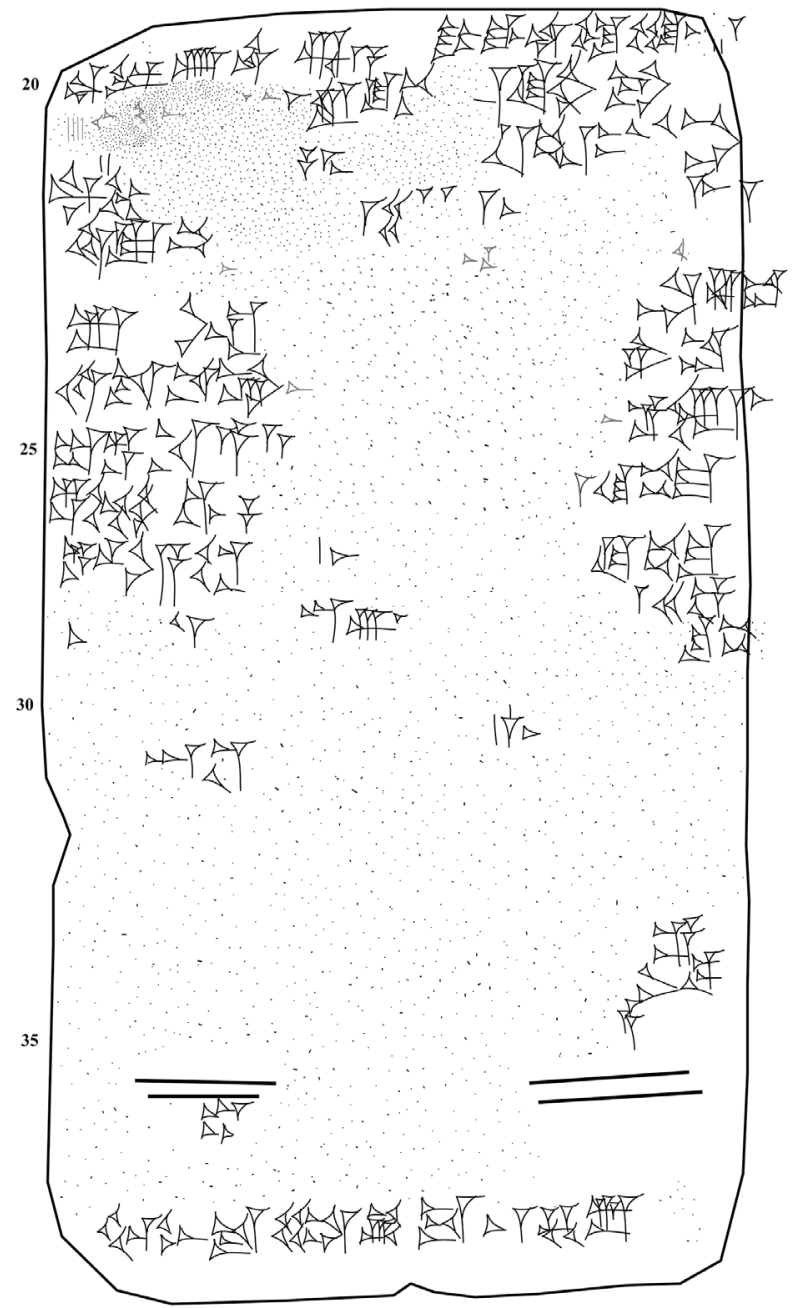

Fig. 2: Emory Museum 2012.44.5 = x.3.220 reverse. Copy: N. Reid 


\section{Transliteration}

Obv.

1 'ù'-mu-un-e Mí.ús-a-' ${ }^{n} i^{1}$ mí zi-dè-eš mu-un-né

1a (vacat) Mí.ús-a-'ni mî́ zi-dè-eš mu-un-né

2 'ù'-mu-un-e dram?-ma?l-an-ki mí zid-eš mu-un-né

3 'ù'-mu-un d[am]?-' 'úru'-ze-ba mí zid-eš mu-un-né

4 èš 'kù? $a b z u$ ??-a ii-DU'-a-ra Mí.ús-a-ni mí zid-eš mu-né

5 še-eb úru-zé-[b]a?-ta i-DU-a-ra Mí.ús-a-ni

6 é-engur-ra- ${ }^{\top} a^{1}$ i-DU-a-ra Mí. 'ús-a-ni ${ }^{1}$

$7 \quad i_{7}-d a$ a-eštublub ${ }_{6}$ e-nir? mí na-mu-un-nél Mí.[ús-a-ni]

8 a- 'šà ${ }^{1}-g a$ še-gu-nu ${ }^{\top} e^{1}-n i r$ mí na-mu-un-né [Mí].ús-a-ni

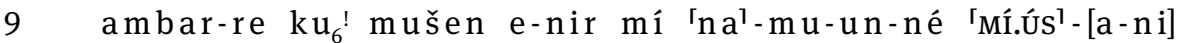

10 mu-gi sumun-né e-nir mí na- ${ }^{\top} m u^{1}-u n-n e ́{ }^{\top}{ }^{1}{ }^{1} \cdot{ }^{\prime}[s-a-n i]$

11 ĝištir-tir-e ši-bar e-nir mí na-mu-un-né 'Mí'.[ús-a-ni]

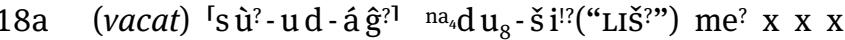

18b (vacat) x? Mí.Ús-a-ni mí zid-eš mu-[u]n-né

égi z[i]?-dè ri-a dumu gal diĝir gal $\langle$ d $\rangle$ nin-tu-[r]e?

Rev.

20 ddam-nun-na ri-a dumu gal dnin-tu- ${ }^{\top} \mathrm{e}^{\text {? }}$

20a (vacat) (ras.) x x x x (x) šub ki - ‘á $\hat{g}^{1}$ ki áb ga [(x)]

21 drda m? - [nun-na](?) x x x ki -áĝ x (x) ga/bi

22 šà kù -g a $[\mathrm{x}$ x x (x)] x x x [x x] x

22a (vacat) $\mathrm{x}[\mathrm{x} \times \mathrm{x}] \mathrm{x}[\mathrm{x} \mathrm{x}] \mathrm{x}$

23 sa $\hat{g}^{?} \times$ la [x x x x x (x)] ta? ri? DU

24 šà da-da-ga $\mathrm{x}[\mathrm{x} \times \mathrm{x} \times \mathrm{x}(\mathrm{x})] \mathrm{NI}$ DU

25 AB e da a ${ }^{\lceil} \mathrm{a}^{?]}[\mathrm{x} \times \mathrm{x} \times(\mathrm{x})] \mathrm{x}$-e sikil-lá

e-gu-up?-pe x $[x \times x]$ x ki-á $\hat{g}$

e - 'gi - a? d a m? x x [x x x] x ki-á $\hat{g}$

$\mathrm{x} x[\mathrm{x}] \mathrm{x}$ x [x x x (x)] x x UD

[ ] 'ki-á $\hat{g}^{?]}$

$[\mathrm{x} \times \mathrm{x} \times \mathrm{x} \times(\mathrm{x})]^{\mathrm{\Gamma} a}{ }^{?]} \mathrm{x}[\mathrm{]}$ $[\mathrm{x}] \mathrm{x} \times[$

[

[

[ ] N-ba

[ ]-a 


\section{Translation}

1 "Lord!" his spouse speaks with kindly words for him, his spouse speaks with kindly words for him,

2 "Lord Amanki (= Enki)!" she speaks with kindly words for him,

3 "Lord, wild-bull of Uruzeb (= Eridu)!” she speaks with kindly words for him,

To the one going(?), (in) the holy shrine, the abzu(?), his spouse (speaks) with kindly words for him,

To the one going(?) from the brickwork of Uruzeb, his spouse (speaks with kindly words for him),

To the one going(?) from the E'engur, his spouse (speaks with kindly words for him),

In the river, the spring waters indeed speak kindly to him, his spouse (speaks with kindly words for him), In the field, the mottled barley indeed speaks kindly to him, his spouse (speaks with kindly words for him), In the marsh, the fish and birds indeed speak kindly to him, his spouse (speaks with kindly words for him), In the thicket, the reed-shoots indeed speak kindly to him, his spouse (speaks with kindly words for him), In the forest, the wild goats indeed speak kindly to him, his spouse (speaks with kindly words for him),

12 In the high steppe, the mašgurum trees indeed [speak] kindly to him, his spouse (speaks with kindly words for him),

13 In the watered gardens, syrup and wine [indeed] speak [kindly] to him, [his spouse] (speaks with kindly words for him),

14 (In) the palace, the long life indeed speaks kindly to him, his spouse (speaks with kindly words for him),

15 The lady, (in) the shrine, the abzu(?), rejoices(?) at him, his spouse (speaks with kindly words for him),

16 Damnuna, (in) the shrine, the abzu(?), rejoices(?) at him, his spouse (speaks with kindly words for him),

17 The god, king of heaven and earth, [...] abundance, his spouse (speaks with kindly words for him).

18 Gold, silver, ..., bronze, copper, tin(?) ..., amber(?), duhšia(?)-stone, ... his spouse speaks with kindly words for him.

19 Born to the good princess, great daughter, great goddess, Nintu,

20 Born to Damnuna, great daughter, Nintu.

21 Dam[nuna](?)... ... beloved(?)

22 In the pure heart ...

$23 \quad \ldots$

24 In the bright heart ...

$25 \quad$... cleaned.

$26 \quad$... beloved(?)

27 Daughter-in-law(?), spouse(?) ... beloved(?)

$28 \quad$...

$29 \quad$... beloved(?)

30-35 (too broken for translation)

36 Š[irnamšub...](?)

37 Long-tablet of li-pí-it-den-líl

\section{Notes}

1. We understand Mí.ús here as probably standing for gitla $\mathrm{m}_{4}$, "spouse," although this orthography is known only from the first millennium BCE (Diri IV 162; for third-millennium BCE attestations of Mí.Ús, not necessar- ily meaning "spouse," but related to male-female relationships, see Bauer 1985). As noted to us by Attinger, the infix $/ \mathrm{n} /$ before the verb /e/ may reflect a directive (compare Attinger 1993, 236), although it cannot refer to a speech to Enki (for which a dative would have been expected). 
2. For the writing di $\mathrm{am}^{\text {? }}-\mathrm{ma} \mathrm{a}^{\text {? }}-\mathrm{an}-\mathrm{ki}$ (rather than the regular Emesal writing dam-an-ki), compare An-Anum II 131 (Litke 1998, 83).

4. The sequence of signs appears also in lines 15 and 16. The sign $\mathrm{AB}$, if the reading $\mathrm{abzu}$ ! is correct, is peculiarly written with a broken vertical at its end (also in line 15, not preserved in line 16), perhaps influenced by the variant writing of this noun with DÉ (á b zu ).

6. The space of the break in this line looks to be too much for just a TA sign when compared to the TA sign almost immediately above in line 5. Justification for reading $\mathrm{TA}$, as we have done here, can be found in line 13 , where the scribe writes a large LÀL. Since the LÀL sign has a similar structure as the TA, the scribe likely wrote a large TA in line 6, much like the large LÀL in line 13. This also makes most sense grammatically.

7-14. These lines contain the literary topos of abundance, see §II above. The form e- $\mathrm{n}$ i r stands for e- n e - e r in the passage preserved in VS 24, 27 // BM 13932: 5-22 (see §IV below). We tentatively understand the first verb as referring to the abundant phenomena speaking actively to Enki, but it is possible that the verb refers to his spouse, and that the first part of the line refers to the place in which she does this.

In line 14, between tir - tir, there is an extra Winkelhaken or at the very least an orthographic sign variation between the two examples of ti r.

16. While one would expect Damgalnuna, we do not emend the text here, since the same form (without gal) appears also in line 20.

18. For parallels to these lines (from Enki Emesal compositions), see Gabbay 2015, no. 65: a+3f., and parallel no. IX, text III (Cohen 1988, 81f.: e+128f.).

\section{A First Millennium BCE Emesal Composition to Enki}

The text preserved in the two first millennium BCE tablets, VAT 22398 (VS 24, 27) and BM 113932, belonging to an Enki Emesal prayer, describes the abundance related to the god Enki, perhaps during a procession coming from the steppe into the city, including a passage that contains the literary topos of abundance discussed above (§II), which is very rare after the Old Babylonian period.

\section{Manuscripts}

A = VAT 22398 (copy: VS 24, 27; photograph of one preserved fragment: Figure 3)

VAT 22398 is one of relatively few Emesal tablets for which a precise archaeological context is known. It was found in the Ishin-Aswad area, northeast of the Ninurta temple in Babylon (Pedersén 2005, 262, no. 193). It may be dated to the Achaemenid period, for two reasons. Firstly, its archaeological context is Neo-Babylonian or early Achaemenid (Pedersén 2005, 248); secondly, it includes performative indications, which are known only from the Achaemenid and later periods (Mirelman 2018, Chapters 4-7). Only one side of the tablet is preserved, and it is uncertain whether this is the obverse or reverse. In its present state in the Vorderasiatisches Museum in Berlin, only a small fragment of the entire tablet is preserved (see Figure 3). Besides Falkenstein's copy published in VS 24, 27 , the tablet's most important witness is an excavation photograph, which we have not been able to access. ${ }^{15}$ The tablet has never been fully edited; only selected lines are cited by Falkenstein (1952-1953).

\section{B = BM 113932 (copy: Figures 4, 5)}

BM 113932 (measurements: $8.8 \mathrm{~cm} \times 4.5 \mathrm{~cm}$ ) was excavated, along with several other Emesal texts, by H. R. Hall at Ur (Geller 2005, 98). What is known about its archaeological context suggests a Neo-Babylonian or Achaemenid date (Gabbay/Mirelman 2011, 274, n.1; Tarasewicz 2018, 55-87), while its inclusion of performative indications points towards an Achaemenid date (Mirelman 2018, chapters 4-7). The beginning of the obverse(?) duplicates VS 24, 27. ${ }^{16}$ The reverse(?) contains an Enki-Marduk litany. The tablet features the common performative indication A directly preceding the half line, and $\mathrm{U}$ in the left margin before u mu n (see, in general, Mirelman 2018, chapter 5).

15 See the description of the tablet by Pedersén $(2005,248)$. The location of the excavation photograph is in Baghdad (p.c. Juliane Eule, Vorderasiatisches Museum, Berlin, February 2017).

16 In fact, what is here called the "reverse" is flatter. Thus, it is possible that our identification of obverse and reverse is incorrect. 


\section{Transliteration}

\section{Segment A}

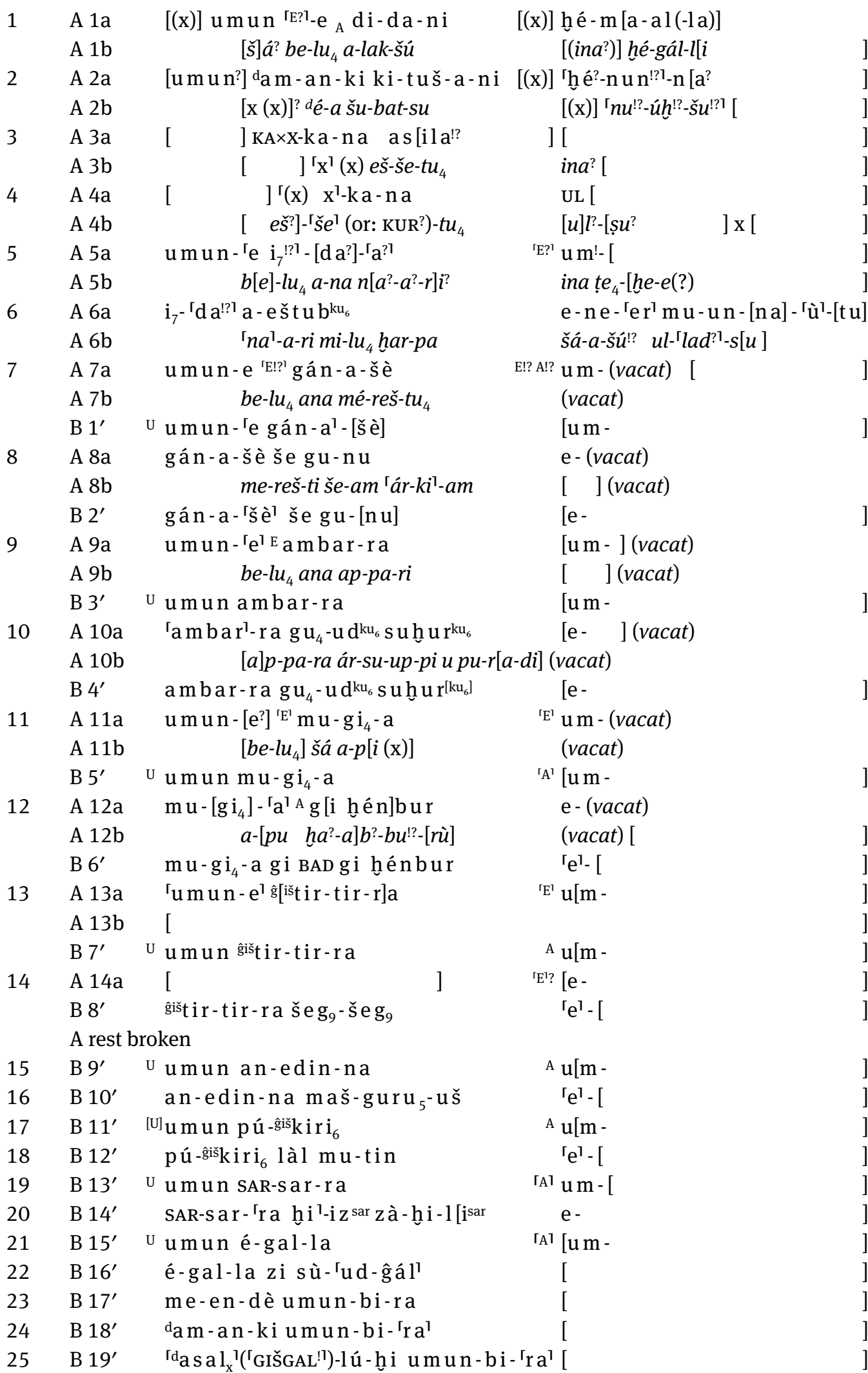




\begin{tabular}{|c|c|}
\hline В $20^{\prime}$ & {$[\mathrm{d} e n-b] i-l u-l u$ umun-bi- ${ }^{\top} \mathrm{ra}^{\top}$} \\
\hline B $21^{\prime}$ & {$\left[{ }^{d} m u-z e ́\right]-e b-b a-s\left[a_{4}-a u m u n-b i-r a\right.$} \\
\hline B $22^{\prime}$ & [dši d-d ù] - ki - šár - r[a \\
\hline B $23^{\prime}$ & {$\left[{ }^{\mathrm{d}} \mathrm{di}\right]-{ }^{\mathrm{r}} \mathrm{k} \mathrm{u}_{5}{ }^{1}-\mathrm{m}$ a h $-[\mathrm{a}$} \\
\hline B $24^{\prime}$ & {$[\quad] \times[$} \\
\hline
\end{tabular}

$\mathrm{B}$ rest broken

\section{Segment B}

\begin{tabular}{|c|c|c|}
\hline $1^{\prime}$ & $\mathrm{B} \mathrm{r.} ?^{\prime}$ & [a m úru-zé]- 'eb-ba $a^{\top}[\mathrm{ki}]$ \\
\hline $2^{\prime}$ & $\mathrm{B} \mathrm{r.} \cdot 2^{\prime}$ & [a ma è š/é]?- ' $\mathrm{mah}{ }^{1}$ \\
\hline $3^{\prime}$ & $\mathrm{Br} \cdot{ }^{3} 3^{\prime}$ & 'gaša n' ddam-gal- 'nun-na' \\
\hline $4^{\prime}$ & $\mathrm{Br} \cdot 4^{\prime}$ & 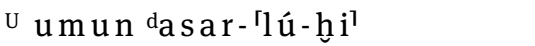 \\
\hline $5^{\prime}$ & $\mathrm{Br} .5^{\prime}$ & $\mathrm{U}$ umun ${ }^{\mathrm{d}+} \mathrm{e}-\mathrm{n}-\mathrm{bi}-\mathrm{lu}-\mathrm{lu}$ \\
\hline $6^{\prime}$ & $\mathrm{B} \mathrm{r.} \cdot 6^{\prime}$ & $\mathrm{d} n \mathrm{ammu}-\mathrm{ke}_{4}$ \\
\hline $7^{\prime}$ & $\mathrm{B} \mathrm{r.} \cdot 7^{\prime}$ & gašan dpa ${ }_{4}-n u n-a n-k i-{ }^{r} e_{4}{ }^{1}$ \\
\hline $8^{\prime}$ & $\mathrm{B} \mathrm{r.} ?^{\prime}{ }^{\prime}$ & dara-e \\
\hline $9^{\prime}$ & B r.? $9^{\prime}$ & dmu-zé-eb-ba-s[a $-a]$ \\
\hline $10^{\prime}$ & B r. $? 10^{\prime}$ & $\mathrm{d} \check{S}_{\mathrm{S}}^{\mathrm{i}} \mathrm{d}^{1}-\mathrm{d} \mathrm{u}-\mathrm{k} \mathrm{i}-\mathrm{s} \mathrm{a} \mathrm{r}-\mathrm{r}[\mathrm{a}]$ \\
\hline $11^{\prime}$ & B r. ${ }^{?} 11^{\prime}$ & ${ }^{d+\Gamma} A G d u m u^{1} n u n-n a$ \\
\hline $12^{\prime}$ & B r.? $12^{\prime}$ & 「ibilaé-saĝ́lil-la \\
\hline $13^{\prime}$ & B r.?13' & ${ }^{r} d u m u^{1}-s a \hat{g} d u r a s ̌-a$ \\
\hline $14^{\prime}$ & B r.? $14^{\prime}$ & 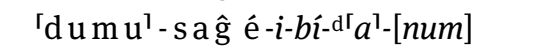 \\
\hline $15^{\prime}$ & B r.? $15^{\prime}$ & 'ga šan ${ }^{1}-g u ̀-t e ́ s ̌-<a>-s i ̀-g a-k e_{4}$ \\
\hline $16^{\prime}$ & B r.? $16^{\prime}$ & 'gašan ${ }^{1}-\hat{g} u_{10}{ }^{d} n a-n a-a$ \\
\hline $17^{\prime}$ & B r.? $17^{\prime}$ & {$[\mathrm{U}] \mathrm{r} u \mathrm{~m}$ un ${ }^{\mathrm{d}} \mathrm{d} \mathrm{i}-\mathrm{k} \mathrm{u}_{5}{ }^{1}-\mathrm{mah}-\mathrm{a}$} \\
\hline $18^{\prime}$ & B r. ${ }^{?} 18^{\prime}$ & $x[x \text { x }(x) x]^{5} b$ a l? en $n^{1}-e x$ \\
\hline $19^{\prime}$ & B r.? $19^{\prime}$ & 'ga ša n? [ $\mathrm{x}$ x x x] [ki?1 \\
\hline $20^{\prime}$ & B r. $? 20^{\prime}$ & $\mathrm{x}[\mathrm{x} \times \mathrm{x}] \mathrm{x} \times$ \\
\hline $21^{\prime}$ & B r. $? 21^{\prime}$ & $\mathrm{x}[\mathrm{x} \times \mathrm{x}] \mathrm{gal} ?$ \\
\hline $22^{\prime}$ & B r.?22' & $\mathrm{x}[$ \\
\hline
\end{tabular}

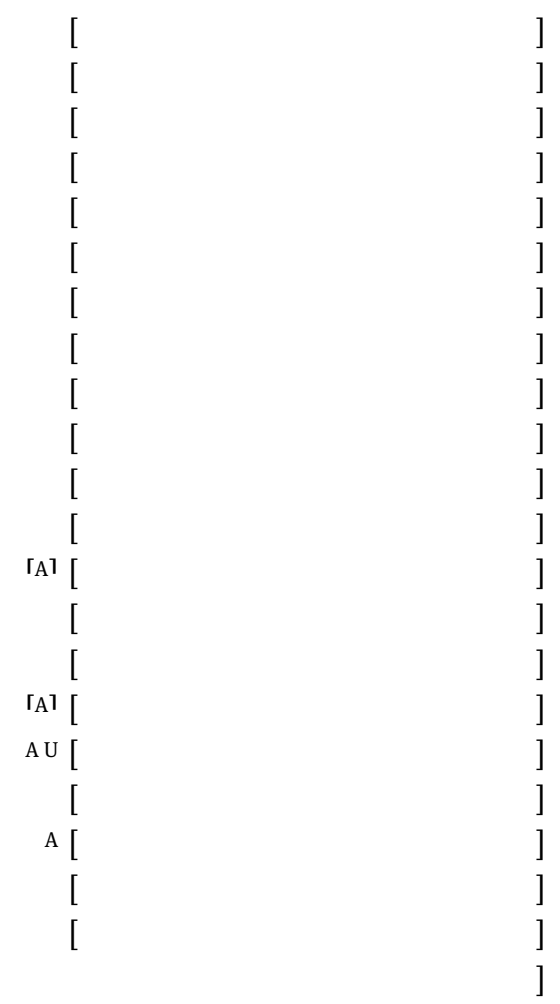

$\mathrm{B}$ rest broken

\section{Translation}

\section{Segment A}

1 The lord - his proceeding is (in) abundance!

2 [(The Lord)] Amanki - his dwelling is (in) plenty!

3 [ ] in his ..., in $\mathrm{j}[\mathrm{oy}(?)$ ]

4 [ ], in his ... - rejoicing(?) [ ]

5 The lord, when app[roaching] the r[iver],

6 The river creates for him spring waters.

7 The lord, when (approaching) the field,

8 The field (creates for him) mottled (Akkadian: late?) barley.

9 The lord, when (approaching) the marsh,

10 The marsh (creates for him) eštub and suhur carps.

11 The lord, when (approaching) the reed-bed, 
12 The reed-bed (creates for him) (reed-shoots and) stalks.

13 The lord, when (approaching) the forests,

14 The forests (create for him) wild sheep.

15 The lord, when (approaching) the high steppe,

16 The high steppe (creates) for him the mašguruš trees.

17 The lord, when (approaching) the irrigated orchard,

18 The irrigated orchard (creates) for him syrup and wine.

19 The lord, when (approaching) the garden,

20 The garden (creates) for him hiz and zahili plants.

21 The lord, [when (approaching)] the palace,

22 The palace (creates for him) long-lasting life!

23 We [ ] to its lord,

24 [ ] to Amanki, its lord,

25 [ ] to Asarluhi, its lord,

26 [ ] to [Enb]ilulu, its lord,

27 [ to Muze]basa'a, [its lord],

28 [ to Šidu]kišara, [its lord,

29 [ to [Di]kumaha, [its lord],

$30 \quad[\quad] \ldots[$ ]

break

\section{Segment B}

$\begin{array}{ll}1^{\prime} & \text { [Bull of Uruz]eb [ } \\ 2^{\prime} & \text { [Mother of Eš]mah [ } \\ 3^{\prime} & \text { Lady Damgalnuna [ } \\ 4^{\prime} & \text { Lord Asarluhi [ } \\ 5^{\prime} & \text { Lord Enbilulu [ } \\ 6^{\prime} & \text { Nammu [ } \\ 7^{\prime} & \text { Lady Panunanki [ } \\ 8^{\prime} & \text { Ara [ } \\ 9^{\prime} & \text { Muzebasa’a [ } \\ 10^{\prime} & \text { Šidukišara [ } \\ 11^{\prime} & \text { Nabû, the princely son [ } \\ 12^{\prime} & \text { Heir of Esaĝil [ } \\ 13^{\prime} & \text { Firstborn of Uraš [ } \\ 14^{\prime} & \text { Firstborn of E-ibbi-Anum [ } \\ 15^{\prime} & \text { Gašan-guteša-siga [ } \\ 16^{\prime} & \text { My-Lady Nanaya [ } \\ 17^{\prime} & \text { Lord Dikumaḩa [ } \\ 18^{\prime} & \text { [ ] ... [ } \\ 19^{\prime} & \text { Lady(?) of(?) [ } \\ 20^{\prime} & \text {... [ } \\ 21^{\prime} & \text {... great [ } \\ 22^{\prime} & \text {... [ }\end{array}$

\section{Notes}

A 3. The horizontal at the beginning of the second half of the Akkadian line may be understood as ina, and this would affect the restoration of lines $1 \mathrm{f}$. But it may be the beginning of a different sign (perhaps RI, for rǐšatu), or the syntax of lines $3 \mathrm{f}$. differs from that of lines $1 \mathrm{f}$. (as indicated by the suffix -na, perhaps a genitive or locative). 

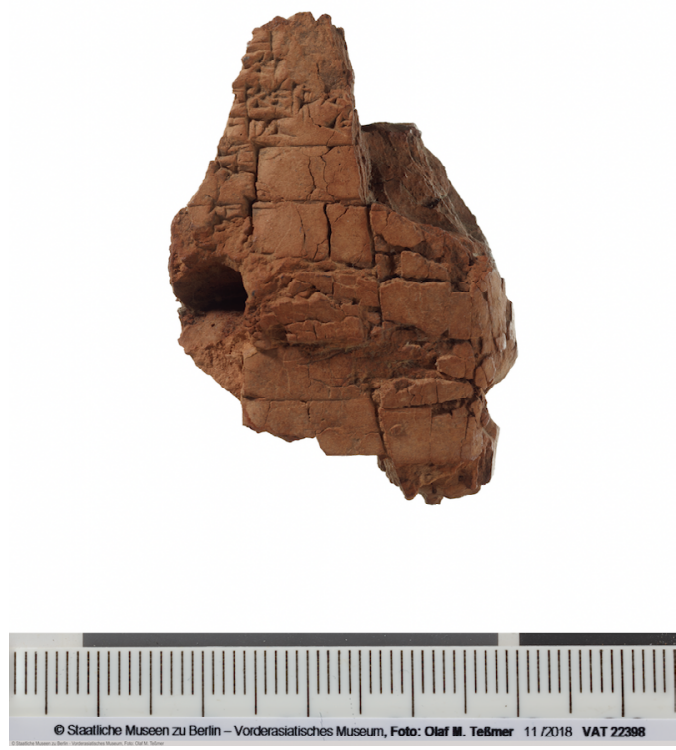

Fig. 3: VAT 22398 (preserved fragment). ( ) Staatliche Museen zu Berlin - Vorderasiatisches Museum. Photograph: Olaf M. Teßmer

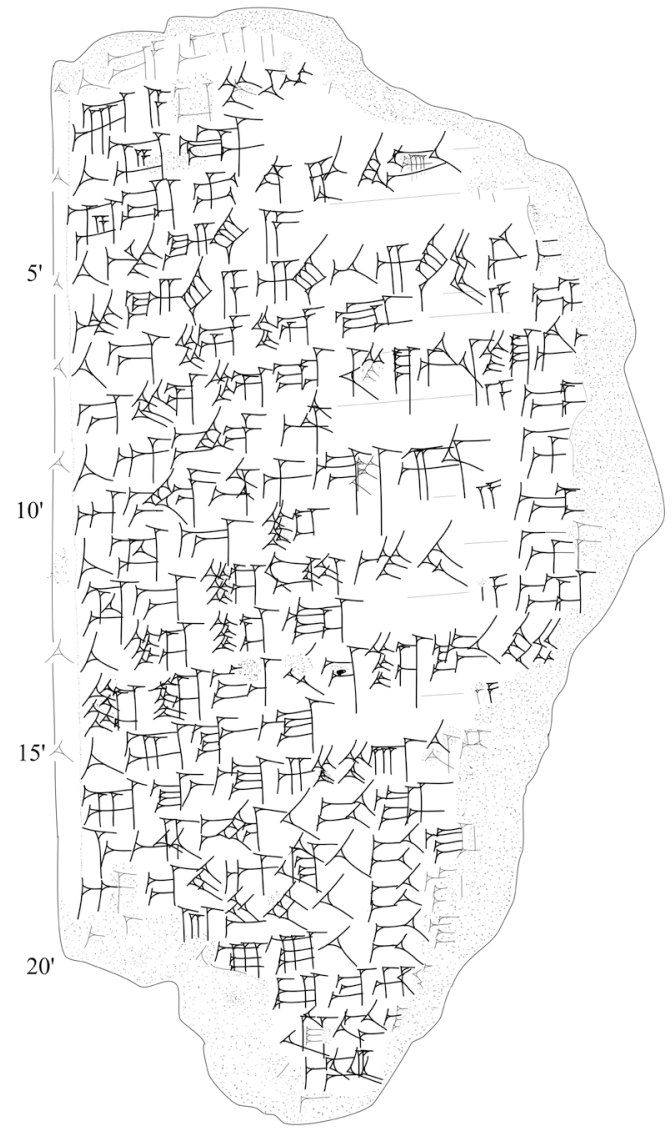

Fig. 4: BM 113932 obverse(?). Copy: S. Mirelman

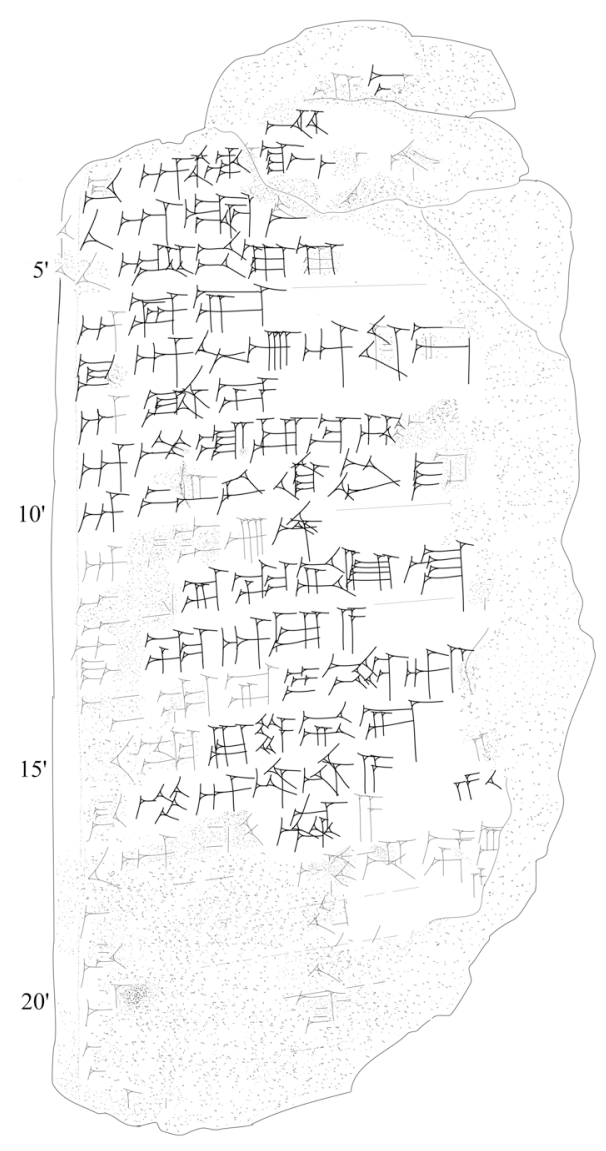

Fig. 5: BM 113932, reverse(?). Copy: S. Mirelman 


\section{References}

Attinger, P. (1993): Eléments de linguistique sumérienne: La construction de $\mathrm{du}_{11} / \mathrm{e} / \mathrm{di}$ “dire.” OBO Sonderband. Fribourg/ Göttingen

Bauer, J. (1985): MUNUS.UŠ. AoN 30

Civil, M. (2003): Reading Gilgameš II: Gilgameš and Hुuwawa, in: W. Sallaberger [e. a.] (eds.), Literatur, Politik und Recht in Mesopotamien. Festschrift für Claus Wilcke. Wiesbaden, 77-86

Cohen, M. E. (1988): The canonical lamentations of ancient Mesopotamia. Maryland

Delnero, P. (2017): The silence of the scribes, pt. II: an unfinished Enlil lament from Nippur, in: L. Feliu [e. a.] (eds.), The first ninety years. A Sumerian celebration in honor of Miguel Civil. SANER 12. Boston/Berlin, 77-97

Falkenstein, A. (1952-1953): Zu einem syllabisch-geschriebenen Emesal-Text, AfO 16, 60-64

Ferrara, A. J. (1973): Nanna-Suen's journey to Nippur. StP sm 2. Rome

- (1995): Topoi and stock-strophes in Sumerian literary tradition: some observations, part I, JNES 54, 81-117

Frayne, D. R. (1990): The royal inscriptions of Mesopotamia, early periods 4: Old Babylonian period. Toronto

Gabbay, U. (2015): The eršema prayers of the first millennium BC. Heidelberger Emesal-Studien 2. Wiesbaden

Gabbay, U./S. Mirelman. (2011): Two summary tablets of balậ compositions with performative indications from Late Babylonian Ur, ZA 101, 274-293

- (2017): Text and performance: tayyartu, "repetition," in a mīs pî-type incantation and an Emesal prayer, ZA 107, 22-34
Geller, M. J. (2005): Catalogue of Late Babylonian Ur texts excavated by Hall, Kaskal 2, 97-100

Kramer, S. N. (1985): BM 23631: bread for Enlil, sex for Inana, Or. 54 , 117-132

Litke, R. L. (1998): A reconstruction of the Assyro-Babylonian god-lists, AN: ${ }^{d} A-n u-u m$ and AN: Anu ša amēli, ed. W. W. Hallo. TBC 3. New Haven

Ludwig. M.-C. (2006): “Enki in Nippur”. Ein bislang unidentifiziertes, mythologisches Fragment, JCS 58, 27-38

Michalowski, P. (1980): A new Sumerian “catalogue” from Nippur, OrAnt. 19, 265-268

Michalowski, P. (1989): The lamentation over the destruction of Sumer and Ur. Winona Lake

Mirelman, S. (2018): Text and performance in the Mesopotamian liturgical tradition. PhD Diss. New York

Pedersén, O. (2005) Archive und Bibliotheken in Babylon. Die Tontafeln der Grabung Robert Koldeweys 1899-1917. Berlin

Peterson, J. (2008): The Sumerian literary fragment N 3381 (JNES 54 117), NABU 2008, no. 53

Römer, W. H. Ph. (2001): Hymnen und Klagelieder in sumerischer Sprache. AOAT 276. Münster

Tarasewicz, R. (2018): The Neo-Babylonian records from Ur from the Hall Collection of the British Museum. Dubsar 7. Münster

Wilcke, C. (1977-78): Review of Ferrara 1973, WO 9, 161-163

Addendum: A new passage with the abundance topos, also in a composition to Enki (Širnamšub), was published after this article was accepted for publication: C. Metcalf, Sumerian literary texts in the Schøyen Collection vol. 1: Literary sources on Old Babylonian religion. CUSAS 38 (University Park, Pa. 2019) no. 4: 74-80. 